Supporting Information for

Environmental Science \& Technology

\title{
Carbon and chlorine isotope effects during abiotic reductive dechlorination of polychlorinated ethanes
}

Thomas B. Hofstetter * \# ${ }^{\circ}$, Christopher M. Reddy \#, Linnea J. Heraty $\neq$, Michael Berg $\dagger$, and Neil C.

Sturchio $\neq$

\# Department of Marine Chemistry and Geochemistry, Woods Hole Oceanographic Institution, Woods Hole, Massachusetts 02543, $\neq$ Department of Earth \& Environmental Sciences, University of Illinois at Chicago, Chicago, Illinois 60607,

* thomas.hofstetter@env.ethz.ch;

${ }^{\circ}$ Institute of Biogeochemistry and Pollutant Dynamics, ETH Zurich, 8092 Zurich, Switzerland;

$\dagger$ Eawag, Swiss Federal Institute of Aquatic Science and Technology, 8600 Dubendorf, Switzerland

April 5, 2007

Pages: 19

Figures: 1

Tables: 5

\section{Contents}

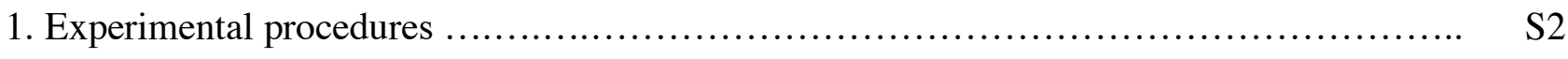

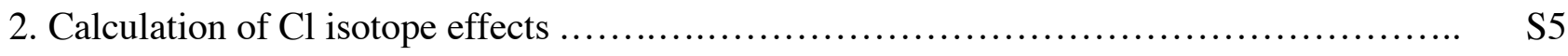

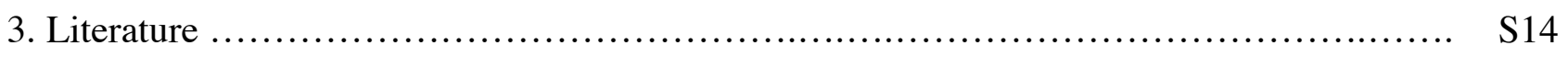




\section{Experimental Procedures}

\section{Chemicals and Reagents}

All chemicals were used as received. Names, purity, and suppliers follow: hexachloroethane (99\%), pentachloroethane (95\%), 1,1,2,2-tetrachloroethane (98\%), tetrachloroethene (99.9\%), trichloroethene (99.5\%), cis-dichloroethene (97\%), trans-dichloroethene (98\%), 3-chlorofluorobenzene (99\%), morpholino-propanesulfonic acid (MOPS, 99.5\%), N-[Tris(hydroxymethyl)methyl]-3aminopropanesulfonic acid (TAPS, 99.5\%), $\mathrm{KNO}_{3}(99.5 \%), \mathrm{AgNO}_{3}(99 \%), \mathrm{Cr}_{2}\left(\mathrm{SO}_{4}\right)_{3} \cdot \mathrm{x} \mathrm{H}_{2} \mathrm{O}$ were supplied by Aldrich. Methanol (HPLC grade) and hexane (GC resolv*) where obtained from Fisher Scientific. $\mathrm{Cr}\left(\mathrm{H}_{2} \mathrm{O}\right)_{6}{ }^{2+}$ was prepared by reducing chromium(III) sulfate hydrate by zinc powder (100 mesh, Alfa Aesar). The preparation of oxygen-free solutions took place in an anaerobic glovebox $\left(\mathrm{N}_{2} / \mathrm{H}_{2}\right.$ atmosphere, ALK 421; Coy Inc., Grass Lake, MI). Nanopure water, buffer solutions were deoxygenated by boiling and subsequent purging with Ar for at least $3 \mathrm{~h}$ until the solutions cooled down to room temperature.

\section{Experimental Systems}

Base-catalyzed dehydrochlorination of pentachloroethane (PCA) and 1,1,2,2-tetrachloroethane $(1,1,2,2-\mathrm{TeCA})$ was investigated as described by (1) at $\mathrm{pH} 7.51 \pm 0.02$ and $8.53 \pm 0.03$ in solutions buffered with morpholino-propanesulfonic acid (MOPS) and N-[Tris(hydroxymethyl)methyl]-3aminopropanesulfonic acid (TAPS), respectively. Reductive $\beta$-elimination of hexachloroethane (HCA), PCA, and 1,1,2,2-TeCA by $\mathrm{Cr}(\mathrm{II})$ was conducted at $\mathrm{Cr}(\mathrm{II})$ concentrations of $1.0 \mathrm{mM}$. $\mathrm{Cr}\left(\mathrm{H}_{2} \mathrm{O}\right)_{6}{ }^{2+}$ was prepared by reducing chromium(III) sulfate hydrate by zinc powder and $\operatorname{Cr}(\mathrm{II})$ concentrations were determined UV/vis spectrometry $(2,3)$. In the glovebox, reactors were prepared by diluting $0.3 \mathrm{M} \mathrm{Cr}$ (II) solution with $1 \mathrm{M} \mathrm{H}_{2} \mathrm{SO}_{4}$ to a final $\mathrm{pH}$ of 2.2 (4). All experiments were carried out in serum bottles sealed with Vitor ${ }^{\circledR}$ rubber stoppers (Maag Technik, Dubendorf, Switzerland) and aluminum crimp caps. Reactors were kept on a shaker table at $23 \pm 1^{\circ} \mathrm{C}$ in the dark. Dechlorination experiments were started by the addition of variable volumes ( 25 to $300 \mu \mathrm{L}$ ) of methanolic stock solution of chlorinated ethane using a gastight glass syringe. Solution volumes and initial concentrations of chlorinated ethane depended on the element investigated isotopically and were for C isotope analysis: $25 \mathrm{~mL}$ and $20 \mu \mathrm{M}$ for dehydrochlorination reactions, and $53 \mathrm{~mL}$ and $190 \mu \mathrm{M}$ for reductive $\beta$-elimination. For each isotope ratio measurement, a single reactor was processed according to the procedure described below. For $\mathrm{Cl}$ isotope analysis reactors always contained $150 \mathrm{~mL}$ of solution but initial concentrations were 120 and $320 \mu \mathrm{M}$ for measurements of $\delta^{37} \mathrm{Cl}$ in chlorinated ethanes and chloride, respectively.

\section{GC-ECD measurements}

For concentration measurements $50 \mu \mathrm{L}$ of aqueous sample were withdrawn from the reactors with a gastight glass syringe and aliquots were extracted with $200 \mu \mathrm{L}$ of hexane containing $300 \mu \mathrm{M}$ of 3chloro-1-fluorobenzene (used as internal standard for quantification) on a vortex mixer for 30 seconds. 
Extracts $(1 \mu \mathrm{L})$ were injected on-column to a Hewlett-Packard 5890 gas chromatograph equipped with electron capture detector, a Rtx-VMS column (60 m, $0.53 \mathrm{~mm}$ i.d., $320 \mu \mathrm{m}$ film thickness). Temperature program started at $40^{\circ} \mathrm{C}$ for $1 \mathrm{~min}$ and increased with $8^{\circ} \mathrm{C} / \mathrm{min}$ to $200^{\circ} \mathrm{C}(2 \mathrm{~min})$ with $\mathrm{He}$ carrier gas flow at $100 \mathrm{kPa}$. The injector and detector temperatures were $250^{\circ} \mathrm{C}$ and $320^{\circ} \mathrm{C}$ respectively, and makeup gas flow was $12 \mathrm{~mL} / \mathrm{min}$ (90\%/10\% argon/methane). Individual chlorinated ethanes and ethenes (reaction products) were identified and quantified by comparison of retention time and peak areas to those of standard samples.

\section{Carbon isotope analyses}

The entire solution of the reactors used for dehydrochlorination experiments were used for $\delta^{13} \mathrm{C}$ isotope analysis of PCA, 1,1,2,2-TeCA and its reaction products after stopping the reaction by injection of $3 \mathrm{M} \mathrm{HNO}_{3}$ to achieve a final solution $\mathrm{pH}$ of 2. Compound-specific isotope analysis (CSIA) was performed on a GC-C-IRMS system (Trace GC/GC Combustion III interface/DeltaPLUS ${ }^{\mathrm{XL}}$ isotope ratio mass spectrometer, Thermo Electron, Bremen, Germany) coupled to a purge and trap concentrator (LSC 3100, Tekmar Dohrmann, Mason, OH) equipped with a liquid auto-sampler (AquaTek 70, Tekmar Dohrmann) according the procedure described in ref. (5). Briefly, diluted aqueous samples from the reactors $(25 \mathrm{~mL})$ were purged for $11 \mathrm{~min}$ with an $\mathrm{N}_{2}$ flow of $40 \mathrm{~mL} / \mathrm{min}$ and trapped on a VOCARB 3000 trap (Supelco, Bellefonte, PA) at room temperature. By heating the trap to $250^{\circ} \mathrm{C}$ for 1 min, analytes were thermally desorbed and transferred to a cryofocusing unit maintained at $-120^{\circ} \mathrm{C}$ using liquid nitrogen. Extraction efficiencies and reproducibility of isotopic measurements were tested for PCA and 1,1,2,2-TeCA as done previously (6), where isotopic fractionation due to the extraction process was below $\pm 0.5 \%$ for $\delta^{13} \mathrm{C}$. For the determination of $\delta^{13} \mathrm{C}$-values of HCA, PCA, and 1,1,2,2TeCA from experiments with $\mathrm{Cr}(\mathrm{II})$, the solution in the reactors was extracted at given time intervals with $2 \mathrm{~mL}$ of hexane after addition of $1 \mathrm{~mL}$ of $4 \mathrm{M} \mathrm{NaCl}$ solution to the aqueous solution. Quantitative extraction was verified by comparing peak areas (measured by GC-ECD) of these extracts to signals obtained for standards in hexane (data not shown). Extracts were injected via a cold on-column injector to the GC-C-IRMS system as described elsewhere (6) yielding precisions (standard deviations) of $\pm 0.3 \%$. All $\delta^{13} \mathrm{C}$-values of the analytes are reported relative to Vienna PeeDee Belemnite $\left(\delta^{13} \mathrm{C}_{\mathrm{VPDB}}\right.$, (7)). Isotopic enrichment was evaluated according to eq. S1 as described in (8),

$$
\ln \left(\mathrm{R}_{\mathrm{C}}\right)=\varepsilon_{\mathrm{C}} / 1000 \cdot \ln (\mathrm{c})+\ln \left(\mathrm{R}_{\mathrm{C}, 0} /\left(\mathrm{c}_{0}\right)\right)
$$

with

$$
\mathrm{R}_{\mathrm{C}}=\mathrm{R}_{\mathrm{C}, \mathrm{VPDB}}\left(\delta^{13} \mathrm{C} / 1000+1\right)
$$

where $\mathrm{R}_{\mathrm{C}}$ equals the $\mathrm{C}$ isotope ratio of the reactant $\left({ }^{13} \mathrm{C} /{ }^{12} \mathrm{C}\right)$ during the reaction (initial value is $\left.\mathrm{R}_{\mathrm{C}, 0}\right)$ and of reference material $\left(\mathrm{R}_{\mathrm{C}, \mathrm{VPDB}}\right)$, respectively, $\varepsilon_{\mathrm{C}}$ is the $\mathrm{C}$ isotope enrichment factor, $\mathrm{c}$ stands for the concentration, and $\delta^{13} \mathrm{C}$ represents the $\mathrm{C}$ isotope signature of the chlorinated ethane defined as 


$$
\delta^{13} \mathrm{C}=\left(\frac{{ }^{13} \mathrm{C} /{ }^{12} \mathrm{C}_{\text {sample }}}{{ }^{13} \mathrm{C} /{ }^{12} \mathrm{C}_{\text {vPDB }}}-1\right) \cdot 1000
$$

From $\varepsilon_{\mathrm{C}}$-values derived for the bulk reactant molecules, bond-specific apparent kinetic isotope effects $\left(\mathrm{AKIE}_{\mathrm{C}}\right)$ can be calculated using assumptions for the number of reactive $\mathrm{C}$ sites in a polychlorinated ethane (see eqs. in main manuscript).

\section{Chlorine isotope analyses}

Aqueous samples were analyzed for $\delta^{37} \mathrm{Cl}$ after complete conversion of HCA, PCA, or 1,1,2,2-TeCA to the corresponding dehydrochlorination or reductive $\beta$-elimination products, tetrachloroethene (PCE), trichloroethene (TCE), or dichloroethenes (DCEs), respectively. Serum bottles containing $150 \mathrm{~mL}$ of aqueous sample corresponding to 60-70 $\mu$ mols of organic $\mathrm{Cl}$ were aspirated into a vacuum line designed for determination of $\mathrm{Cl}$ isotope ratios of chlorinated ethenes and methanes (9). Subsequently, the chlorinated ethene(s) were evacuated and cryogenically isolated in borosilicate tubes containing $\mathrm{CuO}$ (10). Sealed tubes were heated to $550^{\circ} \mathrm{C}$ for $2 \mathrm{~h}$ to form $\mathrm{CuCl}$, which, after removal of excess $\mathrm{CuO}$, is later heated with excess $\mathrm{CH}_{3} \mathrm{I}$ in the same reaction tube to form $\mathrm{CH}_{3} \mathrm{Cl}$. After cryogenic purification $\mathrm{CH}_{3} \mathrm{Cl}$ was then subjected to mass spectrometric analyses using a dual-inlet IRMS (Finnigan Delta Plus ${ }^{\mathrm{XP}}$ ). $\delta^{37} \mathrm{Cl}$ values of the pure starting materials were analyzed following the identical procedure with the exception that pure compounds were directly introduced and evacuated in borosilicate tubes containing predefined amounts of $\mathrm{CuO}$. All $\delta^{37} \mathrm{Cl}$-values are reported relative to Standard Mean Ocean Chloride, $\delta^{37} \mathrm{Cl}_{\mathrm{SMOC}} \equiv 0 \%$ (11).

Analysis of $\delta^{37} \mathrm{Cl}$ from $\mathrm{Cl}$ formed during dechlorination reactions was based on its precipitation as $\mathrm{AgCl}$. After completion of the reactions, samples containing approx. $85 \mu \mathrm{mols}$ of $\mathrm{Cl}^{-}$were evaporated to $10 \mathrm{~mL}$. Ionic strength was adjusted with $1 \mathrm{M} \mathrm{KNO}_{3}$, $\mathrm{pH}$ was buffered with citric acid buffer, and samples were heated to $80^{\circ} \mathrm{C}$ before addition of $3 \mathrm{~mL}$ of $0.4 \mathrm{M} \mathrm{AgNO}_{3}$. After overnight conditioning, $\mathrm{AgCl}$ precipitates were transferred to $50 \mathrm{~mL}$ centrifugation tubes and sample beakers were repeatedly washed with dilute $\mathrm{HNO}_{3}$. Precipitates were suspended in decreasing volumes of dilute $\mathrm{HNO}_{3}$ and centrifuged at $4000 \mathrm{rpm} 5$ times until tubes containing $\mathrm{AgCl}$ were dried in the oven overnight. Comparing weight of $\mathrm{AgCl}$ (approx. $12 \mathrm{mg}$ ) to final concentrations of chlorinated ethenes ensured quantitative precipitation. Silver chloride pellets were transferred into borosilicate tubes and processed with $\mathrm{CH}_{3} \mathrm{I}$ to produce $\mathrm{CH}_{3} \mathrm{Cl}$ for isotopic analyses (12). 


\section{Calculation of $\mathrm{Cl}$ isotope effects}

Chlorine isotope effects were calculated from measured reactant and products $\delta^{37} \mathrm{Cl}$-signatures in per mil (\%o), which are defined as follows

$$
\delta^{37} \mathrm{Cl}=\left(\frac{{ }^{37} \mathrm{R}}{{ }^{37} \mathrm{R}_{\text {SMOC }}}-1\right) \cdot 1000
$$

where ${ }^{37} \mathrm{R}$ is the ${ }^{37} \mathrm{Cl}$ to ${ }^{35} \mathrm{Cl}$ ratio of the compound of interest, and that of a standard material,

${ }^{37} \mathrm{R}_{\mathrm{SMOC}}\left(\right.$ Standard Mean Ocean Chloride, ${ }^{37} \mathrm{R}_{\mathrm{SMOC}}=0.319766$, corresponding to $\delta^{37} \mathrm{Cl} \equiv 0 \%(11)$ ), respectively. Chlorine kinetic isotope effects $\left(\mathrm{KIE}_{\mathrm{Cl}}\right)$, are the ratio of rate constants of reactions involving bond cleavage to ${ }^{35} \mathrm{Cl}\left(\mathrm{k}_{35}\right)$ and ${ }^{37} \mathrm{Cl}$ atoms $\left(\mathrm{k}_{37}\right)$, respectively.

$$
\mathrm{KIE}_{\mathrm{Cl}}=\frac{\mathrm{k}_{35}}{\mathrm{k}_{37}}
$$

This procedure for the derivation of $\mathrm{KIE}_{\mathrm{Cl}}$ is based on the intramolecular isotopic competition for the isotopic dechlorination of ${ }^{35} \mathrm{Cl}$ vs. ${ }^{37} \mathrm{Cl}$ from chlorinated ethanes. In principle, intramolecular $\mathrm{KIE}_{\mathrm{Cl}} \mathrm{S}$ can be calculated from reactant and product isotope signatures given (i) that the reaction proceeds exclusively via one, well-defined mechanism yielding one chlorinated organic product and chloride, (ii) that the initial isotopic composition of the reactant is known, and (iii) that $\mathrm{Cl}$ isotopes are distributed binomially within a molecule. The presented fitting procedure uses measured and calculated $\delta^{37} \mathrm{Cl}$ of reaction products (chlorinated ethenes or chloride) as input parameters and $\mathrm{KIE}_{\mathrm{Cl}}$ as the only adjustable variable. Below, procedures for $\mathrm{KIE}_{\mathrm{Cl}}$ calculation of dehydrochlorination reactions and reductive $\beta$ elimination of polychlorinated ethanes are derived and information pertinent to the calculation is given.

\section{Dehydrochlorination of 1,1,2,2-tetrachloroethane}

The calculation of $\mathrm{KIE}_{\mathrm{Cl}}$ is shown here for the dehydrochlorination of 1,1,2,2-TeCA. As shown in Scheme 1, this reaction leads to elimination of either $\mathrm{H}^{35} \mathrm{Cl}$ or $\mathrm{H}^{37} \mathrm{Cl}$ from the five isotopologues i. For simplicity $\mathrm{Cl}$ atom symbols were omitted and instead, only the masses of light (35, red) and heavy (37, blue) isotopes are displayed. Note that position-specific isotopologues of 1,1,2,2-TeCA for $\mathrm{i}=3$, that is, $\mathrm{E}\left({ }^{37} \mathrm{Cl}_{2}\right)$ vs. $\mathrm{Z}\left({ }^{37} \mathrm{Cl}_{2}\right)$ were not considered. 
Scheme S1: Dehydrochlorination of 1,1,2,2-tetrachloroethane (1,1,2,2-TeCA)

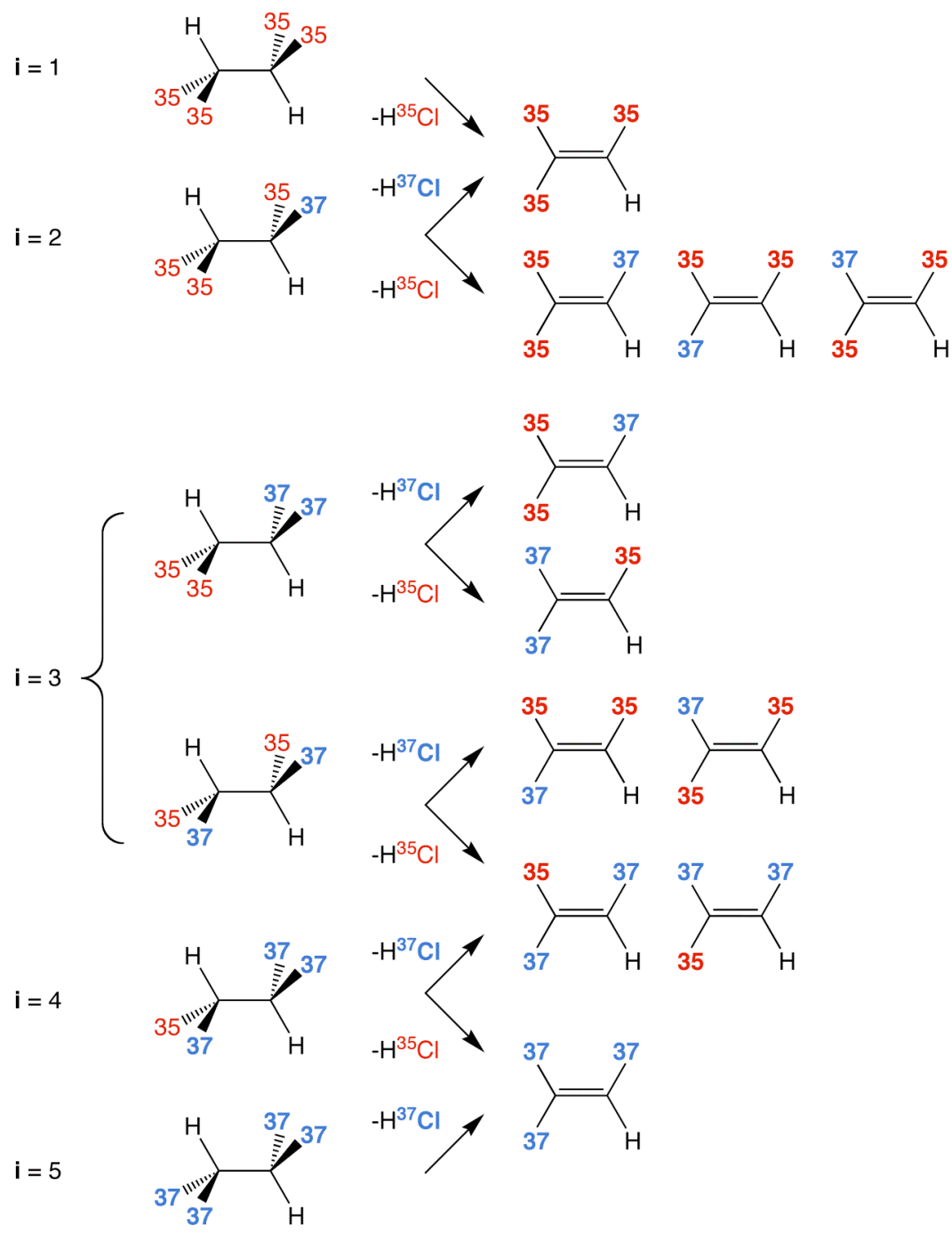

Assuming binomial distribution of the light and heavy Cl-isotopes, the distribution of the 5 1,1,2,2TeCA isotopologues is given by eq. S6 (13)

$$
P_{i}=\left(\begin{array}{c}
n_{C l, i} \\
n_{C l, i}^{37}
\end{array}\right) \cdot \pi_{R}^{n_{C l, i}^{37}} \cdot\left(1-\pi_{R}\right)^{n_{C l, i}-n_{C, i}^{37}}
$$

where $\mathrm{n}_{\mathrm{Cl}, \mathrm{i}}$ is the total number of $\mathrm{Cl}$ atoms and $\mathrm{n}_{\mathrm{Cl}, \mathrm{i}}^{37}$ is the number of ${ }^{37} \mathrm{Cl}$-atoms of isotopologue $\mathbf{i}$. Consequently, the difference $\mathrm{n}_{\mathrm{Cl}, \mathrm{i}}-\mathrm{n}_{\mathrm{Cl}, \mathrm{i}}^{37}$ corresponds to the number of ${ }^{35} \mathrm{Cl}$ atoms. $\pi_{\mathrm{R}}$ is the relative abundance of ${ }^{37} \mathrm{Cl}$ defined as

$$
\pi_{\mathrm{R}}=\frac{{ }^{37} \mathrm{Cl}}{{ }^{35} \mathrm{Cl}+{ }^{37} \mathrm{Cl}}=\frac{{ }^{37} \mathrm{R}_{\mathrm{R} 0}}{{ }^{37} \mathrm{R}_{\mathrm{R} 0}+1}=\frac{\left(\delta^{37} \mathrm{Cl}_{\mathrm{R} 0} / 1000+1\right){ }^{37} \mathrm{R}_{\text {std }}}{\left(\delta^{37} \mathrm{Cl}_{\mathrm{R} 0} / 1000+1\right){ }^{37} \mathrm{R}_{\text {std }}+1}
$$

Given the initial isotope ratio of the reactant, $\delta^{37} \mathrm{Cl}_{\mathrm{R} 0}$ in eq. $\mathrm{S} 8, \pi_{\mathrm{R}}$ can be determined by substituting $\delta^{37} \mathrm{Cl}_{\mathrm{R} 0}$ for the initial isotope ratio, ${ }^{37} \mathrm{R}_{\mathrm{R} 0}$, thus expressing $\pi_{\mathrm{R}}$ in terms of initial reactant $\delta^{37} \mathrm{Cl}$-signature and the isotope ratio of standard material, ${ }^{37} \mathrm{R}_{\text {std }}$, respectively. 


$$
\delta^{37} \mathrm{Cl}_{\mathrm{R} 0}=\left(\frac{{ }^{37} \mathrm{R}_{\mathrm{R} 0}}{{ }^{37} \mathrm{R}_{\mathrm{std}}}-1\right) \cdot 1000
$$

Table S1 lists the relative abundances of the 5 isotopologues of 1,1,2,2-TeCA on the basis of an initial $\delta^{37} \mathrm{Cl}$-signature of $0.060 \%$. Isotopologues containing $1{ }^{37} \mathrm{Cl}$ and $3{ }^{35} \mathrm{Cl}$ atoms are most abundant (42\%) but even molecules containing exclusively ${ }^{37} \mathrm{Cl}$ make up $0.3 \%$ of the total number of molecules.

Table S1 Fractional abundance, $\mathrm{P}_{\mathrm{i}}$, of binomially distributed 1,1,2,2-tetrachloroethane (1,1,2,2TeCA) Cl-isotopologues ${ }^{\mathrm{a}}$ and dehydrochlorination branching ratios for the elimination of $\mathrm{H}^{35} \mathrm{Cl}$ and $\mathrm{H}^{37} \mathrm{Cl}$, respectively.

$\begin{array}{ccccc}\mathrm{i} & \mathrm{n}_{\mathrm{Cl}, \mathrm{i}}^{37} & \mathrm{P}_{\mathrm{i}} & \mathrm{H}^{35} \mathrm{Cl} \text { elimination } & \mathrm{H}^{37} \mathrm{Cl} \text { elimination } \\ \theta_{\mathrm{i}}^{37}\end{array}$

${ }^{a}$ Initial $\delta^{37} \mathrm{Cl}$-signature was $0.060 \%$, $\pi_{\mathrm{R}}$ equals 0.2423 .

According to Scheme S1, dehydrochlorination of 3 out of 5 1,1,2,2-TeCA isotopologues gives rise to intramolecular isotopic competition owing to the simultaneous presence of light and heavy $\mathrm{Cl}$ atoms in the molecule. In contrast, isotopologue $\mathbf{i}=1$ and $\mathbf{i}=5$ do not exhibit intramolecular isotope effect since they are isotopically homogeneous and thus will eliminate either exclusively $\mathrm{H}^{35} \mathrm{Cl}(\mathbf{i}=1)$ or $\mathrm{H}^{37} \mathrm{Cl}(\mathbf{i}=$ $5)$. The rate law for the dehydrochlorination reaction of the five isotopologues can be formulated using a pseudo-first order disappearance rate constant $\Phi_{\mathrm{i}}$ for every isotopologue.

$$
\frac{\mathrm{d}\left[\mathrm{C}_{2}{ }^{35} \mathrm{Cl}_{\left(\mathrm{n}_{\mathrm{Cl}, \mathrm{i}}-\mathrm{n}_{\mathrm{Cl}, \mathrm{i}}^{37}\right)}{ }^{37} \mathrm{Cl}_{\mathrm{n}^{37} \mathrm{Cl}, \mathrm{i}}\right]}{\mathrm{dt}}=\Phi_{\mathrm{i}} \cdot\left[\mathrm{C}_{2}{ }^{35} \mathrm{Cl}_{\left(\mathrm{n}_{\mathrm{Cl}, \mathrm{i}}-\mathrm{n}_{\mathrm{Cl}, \mathrm{i}}{ }^{37}\right)}{ }^{37} \mathrm{Cl}_{\mathrm{n}_{\mathrm{Cl}, \mathrm{i}}^{37}}\right]
$$

This reaction leads to elimination of $\mathrm{H}^{35} \mathrm{Cl}$ or by $\mathrm{H}^{37} \mathrm{Cl}$ and the corresponding elimination rate constants are $\mathrm{k}_{35}$ and $\mathrm{k}_{37}$, respectively. Assuming a normal $\mathrm{KIE}_{\mathrm{Cl}}$ (i.e., $>1$ ), the different number of light and heavy $\mathrm{Cl}$ atoms per isotopologue gives rise to intramolecular competition since isotopologues 
containing more ${ }^{37} \mathrm{Cl}$ atoms will react slightly slower than isotopologues enriched with ${ }^{35} \mathrm{Cl}$. Thus, the overall disappearance rate constant, $\Phi_{\mathrm{i}}$, is the weighted average of the number of carbon bonds to light and heavy $\mathrm{Cl}$ atoms broken at different rates $\mathrm{k}_{35}$ and $\mathrm{k}_{37}$ according to eq. $\mathrm{S} 10$.

$$
\Phi_{\mathrm{i}}=\phi_{\mathrm{i}}^{35}+\phi_{\mathrm{i}}^{37}=\frac{\left(\mathrm{n}_{\mathrm{Cl}, \mathrm{i}}-\mathrm{n}_{\mathrm{Cl}, \mathrm{i}}^{37}\right) \cdot \mathrm{k}_{35}}{\mathrm{n}_{\mathrm{Cl}, \mathrm{i}}}+\frac{\mathrm{n}_{\mathrm{Cl}, \mathrm{i}}^{37} \cdot \mathrm{k}_{37}}{\mathrm{n}_{\mathrm{Cl}, \mathrm{i}}}=\frac{\left(\mathrm{n}_{\mathrm{Cl}, \mathrm{i}}-\mathrm{n}_{\mathrm{Cl}, \mathrm{i}}^{37}\right) \cdot \mathrm{k}_{35}+\mathrm{n}_{\mathrm{Cl}, \mathrm{i}}^{37} \cdot \mathrm{k}_{37}}{\mathrm{n}_{\mathrm{Cl}, \mathrm{i}}}
$$

where $\phi_{i}^{35}$ and $\phi_{i}^{37}$ represent the number of potential $\mathrm{C}_{-}{ }^{35} \mathrm{Cl}$ and $\mathrm{C}-{ }^{37} \mathrm{Cl}$ bonds that can be broken in the dehydrochlorination reaction. Since in this study dechlorination proceeded until completion, the absolute values of the rate constants $k_{35}$ and $k_{37}$ were irrelevant. Instead, we evaluated isotope ratios of the products for isotope fractionation. For these calculations it was necessary to analyze the isotopic composition of the product with regard to its formation from $\mathrm{H}^{35} \mathrm{Cl}$ - vs. $\mathrm{H}^{37} \mathrm{Cl}$-elimination from every reactant isotopologue. The ratio of $\mathrm{H}^{35} \mathrm{Cl}$ - and $\mathrm{H}^{37} \mathrm{Cl}$-elimination relative to the total number of $\mathrm{HCl}$ eliminations per isotopologue $\mathbf{i}$ can be deduced from eq. S10 and is given by

$$
\theta_{\mathrm{i}}^{\mathrm{j}}=\frac{\phi_{\mathrm{i}}^{\mathrm{j}}}{\Phi_{\mathrm{i}}}
$$

This branching ratio can now be further modified to contain the unknown $\mathrm{KIE}_{\mathrm{Cl}}$. After multiplication of eq. $\mathrm{S} 11$ in the numerator and denominator with $\mathrm{k}_{37}{ }^{-1}$, branching ratios of $\mathrm{H}^{35} \mathrm{Cl}$ - vs. $\mathrm{H}^{37} \mathrm{Cl}$-elimination for every isotopologue, $\theta_{\mathrm{i}}^{\mathrm{j}}$, are given as in eqs. S12 and S13 and contain information on the $\mathrm{KIE}_{\mathrm{Cl}}$ of the dehydrochlorination:

$$
\begin{aligned}
& \theta_{\mathrm{i}}^{35}=\frac{\left(\mathrm{n}_{\mathrm{Cl}, \mathrm{i}}-\mathrm{n}_{\mathrm{Cl}, \mathrm{i}}^{37}\right) \cdot \mathrm{k}_{35}}{\left(\mathrm{n}_{\mathrm{Cl}, \mathrm{i}}-\mathrm{n}_{\mathrm{Cl}, \mathrm{i}}^{37}\right) \cdot \mathrm{k}_{35}+\mathrm{n}_{\mathrm{Cl}, \mathrm{i}}^{37} \cdot \mathrm{k}_{37}}=\frac{\left(\mathrm{n}_{\mathrm{Cl}, \mathrm{i}}-\mathrm{n}_{\mathrm{Cl}, \mathrm{i}}^{37}\right) \cdot \mathrm{KIE}_{\mathrm{Cl}}}{\left(\mathrm{n}_{\mathrm{Cl}, \mathrm{i}}-\mathrm{n}_{\mathrm{Cl}, \mathrm{i}}^{37}\right) \cdot \mathrm{KIE}_{\mathrm{Cl}}+\mathrm{n}_{\mathrm{Cl}, \mathrm{i}}^{37}} \\
& \theta_{\mathrm{i}}^{37}=\frac{\mathrm{n}_{\mathrm{Cl}, \mathrm{i}}^{37} \cdot \mathrm{k}_{37}}{\left(\mathrm{n}_{\mathrm{Cl}, \mathrm{i}}-\mathrm{n}_{\mathrm{Cl}, \mathrm{i}}^{37} \cdot \mathrm{k}_{35}+\mathrm{n}_{\mathrm{Cl}, \mathrm{i}}^{37} \cdot \mathrm{k}_{37}\right.}=\frac{\mathrm{n}_{\mathrm{Cl}, \mathrm{i}}^{37}}{\left(\mathrm{n}_{\mathrm{Cl}, \mathrm{i}}-\mathrm{n}_{\mathrm{Cl}, \mathrm{i}}^{37}\right) \cdot \mathrm{KIE}_{\mathrm{Cl}}+\mathrm{n}_{\mathrm{Cl}, \mathrm{i}}^{37}}
\end{aligned}
$$

The explicit branching ratios of 1,1,2,2-TeCA-dehydrochlorination for all isotopologues are shown in Table S1. Note that the sum of $\mathrm{H}^{35} \mathrm{Cl}$ and $\mathrm{H}^{37} \mathrm{Cl}$ branching ratios is necessarily unity. In the absence of any isotope effect branching ratios obviously correspond to the ratio of the numbers of light and heavy $\mathrm{Cl}$ atoms per isotopologue.

After complete transformation, the ratio of ${ }^{35} \mathrm{Cl}$ and ${ }^{37} \mathrm{Cl}$ in the product is determined by the occurrence of intramolecular isotopic competition. Since the product's isotope ratio sums over all ${ }^{35} \mathrm{Cl}$ and ${ }^{37} \mathrm{Cl}$-atoms in the product isotopologues, one can calculate the contribution of either $\mathrm{H}^{35} \mathrm{Cl}$ or $\mathrm{H}^{37} \mathrm{Cl}$ elimination from the reactant isotopologues $\mathbf{i}$ to the final concentration of ${ }^{35} \mathrm{Cl}$ and ${ }^{37} \mathrm{Cl}$ in the product. For this purpose, we defined isotopic yields. For example, the ${ }^{35} \mathrm{Cl}$-yield, ${ }^{35} \mathrm{y}_{\mathrm{i}, \mathrm{j}}$, quantifies the fraction of ${ }^{35} \mathrm{Cl}$ atoms ending up in the dehydrochlorination product after either elimination of $\mathrm{H}^{35} \mathrm{Cl}\left({ }^{35} \mathrm{y}_{\mathrm{i}, 35}\right)$ or $\mathrm{H}^{37} \mathrm{Cl}\left({ }^{35} \mathrm{y}_{\mathrm{i}, 37}\right)$ per isotopologue. Mathematically, isotopic yields, ${ }^{\mathrm{j}} \mathrm{y}_{\mathrm{i}, \mathrm{j}}$, are products of the initial isotopologue concentration, $\mathrm{P}_{\mathrm{i}}$, the branching ratio of the isotopic reaction, $\theta_{\mathrm{i}}^{\mathrm{j}}$, and the number of ${ }^{35} \mathrm{Cl}$ 
and ${ }^{37} \mathrm{Cl}$-atoms in the product isotopologues $\left(\mathrm{n}_{\mathrm{P}, \mathrm{i}}^{35}\right.$ and $\mathrm{n}_{\mathrm{P}, \mathrm{i}}^{37}$, respectively). Therefore, as shown in eq. $\mathrm{S} 14$, the contribution of $\mathrm{H}^{35} \mathrm{Cl}$ elimination of isotopologue $\mathbf{i}$ to the ${ }^{35} \mathrm{Cl}$-concentration in the product, ${ }^{35} \mathrm{y}_{\mathrm{i}, 35}$ is

$$
{ }^{35} \mathrm{y}_{\mathrm{i}, 35}=\mathrm{P}_{\mathrm{i}} \cdot \theta_{\mathrm{i}}^{35} \cdot \mathrm{n}_{\mathrm{P}, \mathrm{i}}^{35}
$$

Superscripts denote the isotope considered in the product, superscripts indicate eliminated $\mathrm{Cl}$ isotope, $P_{i}$ is the fractional amount of isotopologue $\mathbf{i}$ of the reactant, $\theta_{i}^{35}$ is its ${ }^{35} \mathrm{Cl}$-elimination branching ratio, and $\mathrm{n}_{\mathrm{P}, \mathrm{i}}^{35}$ corresponds to the number of ${ }^{35} \mathrm{Cl}$ atoms in the product arising from this particular reaction. Note that the elimination of ${ }^{37} \mathrm{Cl}$ also contributes to the product's ${ }^{35} \mathrm{Cl}$-concentration as follows:

$$
{ }^{35} \mathrm{y}_{\mathrm{i}, 37}=\mathrm{P}_{\mathrm{i}} \cdot \theta_{\mathrm{i}}^{37} \cdot \mathrm{n}_{\mathrm{P}, \mathrm{i}}^{35}
$$

Thus, the final ${ }^{35} \mathrm{Cl}$ - and ${ }^{37} \mathrm{Cl}$-concentration in the product $\left({ }^{35} \mathrm{Cl}_{\mathrm{P}}\right.$ and $\left.{ }^{37} \mathrm{Cl}_{\mathrm{P}}\right)$ are the sum of $\mathrm{H}^{35} \mathrm{Cl}$ $\left({ }^{35} \mathrm{y}_{\mathrm{i}, 35}\right)$ and $\mathrm{H}^{37} \mathrm{Cl}$-elimination yields over all isotopologues ( $\mathrm{n}$ equals the total number of reactant isotopologues eqs. S16 and S17).

$$
\begin{aligned}
& { }^{35} \mathrm{Cl}_{\mathrm{P}}=\sum_{\mathrm{i}=1-\mathrm{n} ;}{ }^{35} \mathrm{y}_{\mathrm{i}, 35}+\sum_{\mathrm{i}=1-\mathrm{n} ;}{ }^{35} \mathrm{y}_{\mathrm{i}, 37}=\sum_{\mathrm{i}=1-\mathrm{n} ;} \mathrm{P}_{\mathrm{i}} \cdot \theta_{\mathrm{i}}^{35} \cdot \mathrm{n}_{\mathrm{P}, \mathrm{i}}^{35}+\sum_{\mathrm{i}=1-\mathrm{n} ;} \mathrm{P}_{\mathrm{i}} \cdot \theta_{\mathrm{i}}^{37} \cdot \mathrm{n}_{\mathrm{P}, \mathrm{i}}^{35} \\
& { }^{37} \mathrm{Cl}_{\mathrm{P}}=\sum_{\mathrm{i}=1-\mathrm{n} ;}{ }^{37} \mathrm{y}_{\mathrm{i}, 35}+\sum_{\mathrm{i}=1-\mathrm{n} ;}{ }^{37} \mathrm{y}_{\mathrm{i}, 37}=\sum_{\mathrm{i}=1-\mathrm{n} ;} \mathrm{P}_{\mathrm{i}} \cdot \theta_{\mathrm{i}}^{35} \cdot \mathrm{n}_{\mathrm{P}, \mathrm{i}}^{37}+\sum_{\mathrm{i}=1-\mathrm{n} ;} \mathrm{P}_{\mathrm{i}} \cdot \theta_{\mathrm{i}}^{37} \cdot \mathrm{n}_{\mathrm{P}, \mathrm{i}}^{37}
\end{aligned}
$$

Finally, the ratio of eqs. S16 and S17 corresponds to the product's isotope ratio, ${ }^{37} \mathrm{R}_{\mathrm{P}}$, and can be converted to the products $\delta^{37} \mathrm{Cl}$-signature.

$$
\delta{ }^{37} \mathrm{Cl}_{\mathrm{P}}=\left(\frac{{ }^{37} \mathrm{R}_{\mathrm{P}}}{{ }^{37} \mathrm{R}_{\text {std }}}-1\right) \cdot 1000=\left(\frac{{ }^{37} \mathrm{Cl}_{\mathrm{P}} /{ }^{35} \mathrm{Cl}_{\mathrm{P}}}{{ }^{37} \mathrm{R}_{\text {std }}}-1\right) \cdot 1000
$$

This calculated product isotope signature can now be compared to measured values with $\mathrm{KIE}_{\mathrm{Cl}} \mathrm{S}$ in eqs S12 and S13 being the only adjustable variable. The entire procedure can be set up in spreadsheet calculation software such as Excel. To account for measurement uncertainties in ${ }^{37} \mathrm{R}_{\mathrm{P}}$, Uncertainties of $\mathrm{KIE}_{\mathrm{Cl}} \mathrm{S}$ reflect the measurement uncertainties $\left( \pm 1 \sigma\right.$ of $\left.\delta^{37} \mathrm{Cl}_{\mathrm{P}}\right)$, which was propagated with the described procedure assuming that all other parameters included in the isotopic yields were free of error. 


\section{Dehydrochlorination of pentachloroethane}

For the dehydrochlorination of pentachloroethane, PCA, the identical calculation procedure can be applied. As is shown in Scheme S2, PCA dehydrochlorination can only lead to Cl elimination at the $\alpha$ C atom.

Scheme S2: Dehydrochlorination of pentachloroethane (PCA)

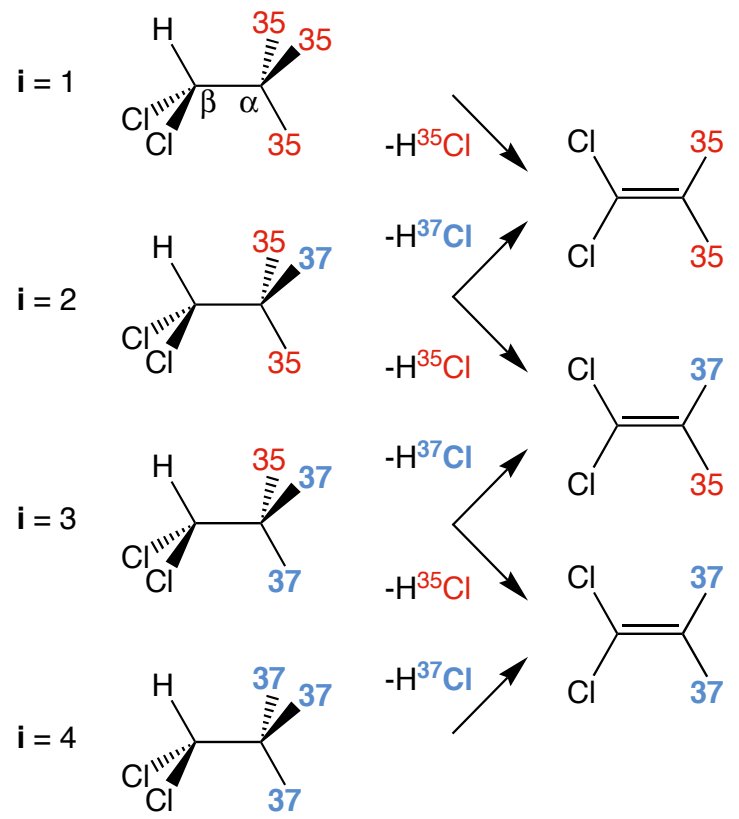

Therefore, the abundance of ${ }^{35} \mathrm{Cl}$ - and ${ }^{37} \mathrm{Cl}$-atoms at the $\beta-\mathrm{C}$ have to be considered as non-reactive contribution to the compounds $\delta^{37} \mathrm{Cl}$-signature in the product $\left({ }^{35} \mathrm{Cl}_{\mathrm{nr}}\right.$ and ${ }^{37} \mathrm{Cl}_{\mathrm{nr}}$, are the isotope abundances of non-reactive $\mathrm{Cl}, \mathrm{n}_{\mathrm{R}, \mathrm{nr}}^{\mathrm{j}}$ are the number of non-reactive atoms in the reactant). This led to to the following, modified versions of eqs. S16 and S17:

$$
\begin{aligned}
& { }^{35} \mathrm{Cl}_{\mathrm{P}}=\sum_{\mathrm{i}=1-\mathrm{n} ;} \mathrm{P}_{\mathrm{i}} \cdot \theta_{\mathrm{i}}^{35} \cdot \mathrm{n}_{\mathrm{P}, \mathrm{i}}^{35}+\sum_{\mathrm{i}=1-\mathrm{n} ;} \mathrm{P}_{\mathrm{i}} \cdot \theta_{\mathrm{i}}^{37} \cdot \mathrm{n}_{\mathrm{P}, \mathrm{i}}^{35}+{ }^{35} \mathrm{Cl}_{\mathrm{nr}} \cdot \mathrm{n}_{\mathrm{R}, \mathrm{nr}}^{35} \\
& { }^{37} \mathrm{Cl}_{\mathrm{P}}=\sum_{\mathrm{i}=1-\mathrm{n} ;} \mathrm{P}_{\mathrm{i}} \cdot \theta_{\mathrm{i}}^{35} \cdot \mathrm{n}_{\mathrm{P}, \mathrm{i}}^{37}+\sum_{\mathrm{i}=1-\mathrm{n} ;} \mathrm{P}_{\mathrm{i}} \cdot \theta_{\mathrm{i}}^{37} \cdot \mathrm{n}_{\mathrm{P}, \mathrm{i}}^{37}+{ }^{37} \mathrm{Cl}_{\mathrm{nr}} \cdot \mathrm{n}_{\mathrm{R}, \mathrm{nr}}^{37}
\end{aligned}
$$

Table S2 lists relative abundances of PCA isotopologues and dehydrochlorination branching ratios for calculation of $\mathrm{KIE}_{\mathrm{Cl}} \mathrm{s}$. The influence of the $\delta^{37} \mathrm{Cl}$-signature of non-reactive $\mathrm{Cl}$ atoms attached to the $\beta-\mathrm{C}$ in PCA is shown in Figure S1 (see manuscript for discussion). 


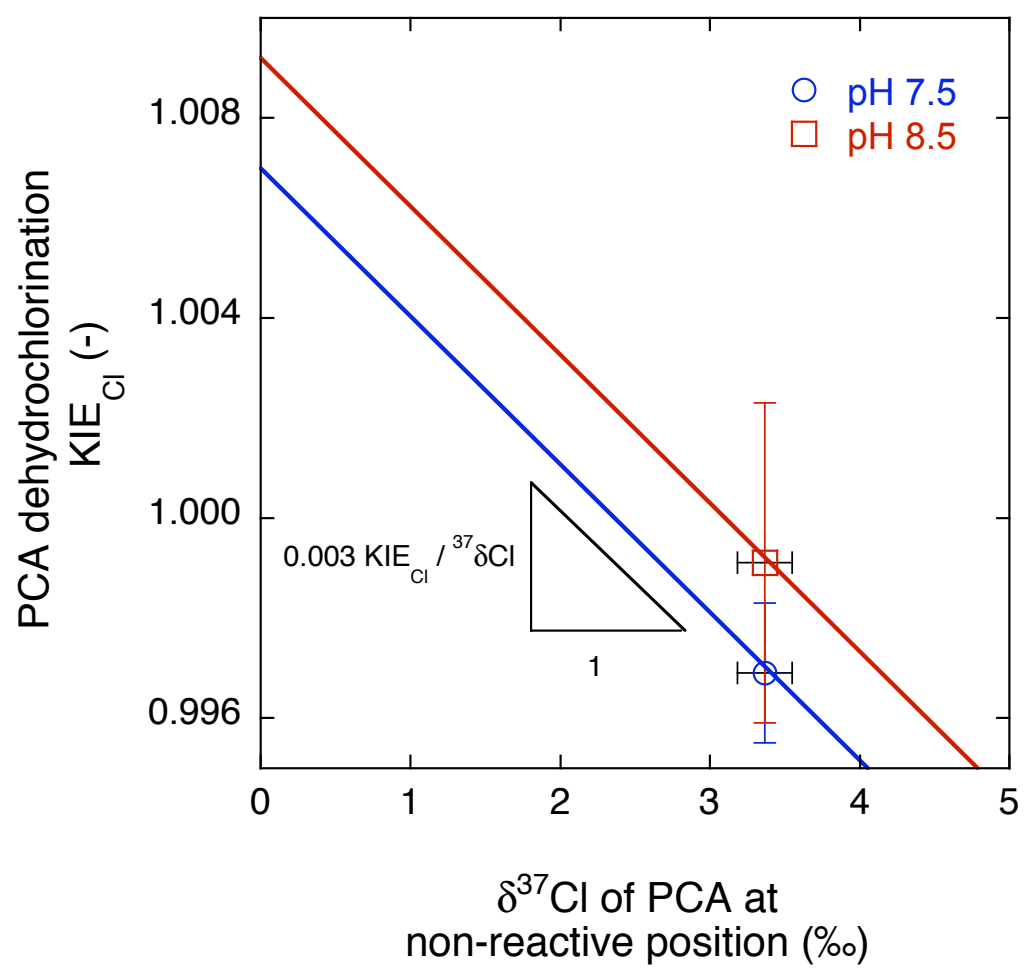

Figure S1 Influence of $\delta^{37} \mathrm{Cl}$ signatures of non-reactive $\beta-\mathrm{Cl}$ of PCA (pentachloroethane) on calculated $\mathrm{KIE}_{\mathrm{Cl}}$ for dehydrochlorination of PCA to tetrachloroethene at $\mathrm{pH} 7.5$ and 8.5, respectively. A deviation of $\delta^{37} \mathrm{Cl}$-values for non- reactive $\mathrm{Cl}$ atoms from binomial intramolecular $\mathrm{Cl}$ isotope distribution (see eq. S6) by $-1 \%$ causes shifts in $\mathrm{KIE}_{\mathrm{Cl}}$ by +0.003 . Errors represent $\pm 1 \sigma$ with regard to measured $\mathrm{\delta}^{37} \mathrm{Cl}$ of initial PCA signature and $\mathrm{KIE}_{\mathrm{Cl}}$. 
Table S2 Fractional abundance, $\mathrm{P}_{\mathrm{i}}$, of binomially distributed pentachloroethane (PCA) Clisotopologues ${ }^{\mathrm{a}}$ and dehydrochlorination branching ratios for the elimination of $\mathrm{H}^{35} \mathrm{Cl}$ and $\mathrm{H}^{37} \mathrm{Cl}$, respectively.
i$$
\mathrm{n}_{\mathrm{Cl}, \mathrm{i}}^{37}
$$
$\mathrm{P}_{\mathrm{i}}$
$\mathrm{H}^{35} \mathrm{Cl}$ elimination
$\theta_{\mathrm{i}}^{35}$
$\mathrm{H}^{37} \mathrm{Cl}$ elimination
$\theta_{\mathrm{i}}^{37}$

\begin{tabular}{ccccc}
\hline 1 & 0 & 0.4339 & 1 & - \\
2 & 1 & 0.4177 & $2 \cdot \mathrm{KIE}_{\mathrm{Cl}} /\left(2 \cdot \mathrm{KIE}_{\mathrm{Cl}}+1\right)$ & $1 /\left(2 \cdot \mathrm{KIE}_{\mathrm{Cl}}+1\right)$ \\
3 & 2 & 0.1340 & $\mathrm{KIE}_{\mathrm{Cl}} /\left(\mathrm{KIE}_{\mathrm{Cl}}+2\right)$ & $1 /\left(\mathrm{KIE}_{\mathrm{Cl}}+2\right)$ \\
4 & 3 & 0.0143 & - & 1
\end{tabular}

${ }^{\text {a }}$ Initial $\delta^{37} \mathrm{Cl}$-signature was $3.367 \%$ o, $\pi_{\mathrm{R}}$ equals 0.2429 . Note that $\delta^{37} \mathrm{Cl}$-signature of two $\mathrm{Cl}$-atoms at the $\beta$-C position were assumed to remain constant during the reaction.

\section{Reductive $\beta$-elimination of 1,1,2,2-tetrachloroethane, pentachloroethane, and hexachloroethane}

In contrast to the dehydrochlorination reactions, two $\mathrm{Cl}$ atoms are eliminated sequentially from the chlorinated ethanes upon reductive $\beta$-elimination. Therefore, we distinguished between isotope effects upon initial reductive dechlorination, $\mathrm{KIE}_{\mathrm{Cl}}(1)$, and subsequent chloride elimination, $\mathrm{KIE}_{\mathrm{Cl}}(2)$. Since in principle both dechlorination steps can be isotopic, 4 different dechlorination pathways were considered in the calculation: (a) ${ }^{35} \mathrm{Cl}-{ }^{35} \mathrm{Cl}$-, (b) ${ }^{35} \mathrm{Cl}-{ }^{37} \mathrm{Cl}-$, (c) ${ }^{37} \mathrm{Cl}-{ }^{35} \mathrm{Cl}$-, and (d) ${ }^{37} \mathrm{Cl}-{ }^{37} \mathrm{Cl}$-elimination. Owing to this approach, additional assumptions with regard to the intramolecular distribution of ${ }^{35} \mathrm{Cl}$ and ${ }^{37} \mathrm{Cl}$-atoms at the $\alpha-\mathrm{C}$ and $\beta-\mathrm{C}$ atoms and the corresponding fractional abundance of isotopologues were necessary. To this end, $\mathrm{n}_{\mathrm{Cl}, \mathrm{i}}^{37}(\alpha)$ and $\mathrm{n}_{\mathrm{Cl}, \mathrm{i}}^{37}(\beta)$ denoting the number of ${ }^{37} \mathrm{Cl}$ atoms at the $\alpha-\mathrm{C}$ and $\beta$ $\mathrm{C}$ atoms are included in Tables S3-S5. Isotopic branching ratios, taking into account two sequential isotope effects, were defined for different 1,1,2,2-TeCA isotopologues and are described in Table S3. Similarly, branching ratios for PCA and hexachloroethane (HCA) are given in Tables S4 and S5, respectively. As illustrative example, the derivation of the branching ratios for reactions of isotopologue $\mathbf{i}=2$ is shown below. Branching ratios of other isotopologues can be calculated likewise.

Isotopologue $\mathbf{i}=2$ of $1,1,2,2-\mathrm{TeCA}$ contains one ${ }^{37} \mathrm{Cl}$ atom. Therefore, only reductive $\beta$-elimination of ${ }^{35} \mathrm{Cl}-{ }^{35} \mathrm{Cl}-,{ }^{35} \mathrm{Cl}-{ }^{37} \mathrm{Cl}$-, and ${ }^{37} \mathrm{Cl}^{35} \mathrm{Cl}$-atoms is possible and $\theta_{\mathrm{i}=2}^{37 / 37}$ is not defined. If $\mathrm{k}_{35}^{(1)}$ and $\mathrm{k}_{35}^{(2)}$ denote the initial and subsequent elimination of a ${ }^{35} \mathrm{Cl}$-atom, respectively, and $\mathrm{k}_{37}^{(1)}$ and $\mathrm{k}_{37}^{(2)}$ are the corresponding terms for ${ }^{37} \mathrm{Cl}$-elimination, branching ratios are 


$$
\begin{aligned}
& \theta_{\mathrm{i}=2}^{35 / 35}=\frac{4 \cdot \mathrm{k}_{35}^{(1)} \cdot \mathrm{k}_{35}^{(2)}}{4 \cdot \mathrm{k}_{35}^{(1)} \cdot \mathrm{k}_{35}^{(2)}+2 \cdot \mathrm{k}_{35}^{(1)} \cdot \mathrm{k}_{37}^{(2)}+2 \cdot \mathrm{k}_{37}^{(1)} \mathrm{k}_{35}^{(2)}} \\
& \theta_{\mathrm{i}=2}^{35 / 37}=\frac{2 \cdot \mathrm{k}_{35}^{(1)} \cdot \mathrm{k}_{37}^{(2)}}{4 \cdot \mathrm{k}_{35}^{(1)} \cdot \mathrm{k}_{35}^{(2)}+2 \cdot \mathrm{k}_{35}^{(1)} \cdot \mathrm{k}_{37}^{(2)}+2 \cdot \mathrm{k}_{37}^{(1)} \mathrm{k}_{35}^{(2)}} \\
& \theta_{\mathrm{i}=2}^{37 / 35}=\frac{2 \cdot \mathrm{k}_{37}^{(1)} \mathrm{k}_{35}^{(2)}}{4 \cdot \mathrm{k}_{35}^{(1)} \cdot \mathrm{k}_{35}^{(2)}+2 \cdot \mathrm{k}_{35}^{(1)} \cdot \mathrm{k}_{37}^{(2)}+2 \cdot \mathrm{k}_{37}^{(1)} \mathrm{k}_{35}^{(2)}}
\end{aligned}
$$

In analogy to the rearrangements of eqs. S12 and S13, these branching ratios can be rewritten by substituting $\mathrm{k}_{35}^{(\mathrm{j})} / \mathrm{KIE}(\mathrm{j})$ for $\mathrm{k}_{37}^{(\mathrm{j})}$

$$
\theta_{\mathrm{i}=2}^{35 / 35}=\frac{4 \cdot \mathrm{k}_{35}^{(1)} \cdot \mathrm{k}_{35}^{(2)}}{4 \cdot \mathrm{k}_{35}^{(1)} \cdot \mathrm{k}_{35}^{(2)}+2 \cdot \mathrm{k}_{35}^{(1)} \cdot \mathrm{k}_{35}^{(2)} / \mathrm{KIE}_{\mathrm{Cl}}(2)+2 \cdot \mathrm{k}_{35}^{(1)} / \mathrm{KIE}_{\mathrm{Cl}}(1) \cdot \mathrm{k}_{35}^{(2)}}
$$

After multiplication of numerator and denominator with $\left(\mathrm{k}_{35}^{(1)} \cdot \mathrm{k}_{35}^{(2)}\right)^{-1}$, the branching ratios simplify to

$$
\begin{aligned}
\theta_{\mathrm{i}=2}^{35 / 35} & =\frac{4}{4+2 / \mathrm{KIE}_{\mathrm{Cl}}(2)+2 / \mathrm{KIE}_{\mathrm{Cl}}(1)} \\
\theta_{\mathrm{i}=2}^{35 / 37} & =\frac{2 / \mathrm{KIE}_{\mathrm{Cl}}(2)}{4+2 / \mathrm{KIE}_{\mathrm{Cl}}(2)+2 / \mathrm{KIE}_{\mathrm{Cl}}(1)} \\
\theta_{\mathrm{i}=2}^{37 / 35} & =\frac{2 / \mathrm{KIE}_{\mathrm{Cl}}(1)}{4+2 / \mathrm{KIE}_{\mathrm{Cl}}(2)+2 / \mathrm{KIE}_{\mathrm{Cl}}(1)}
\end{aligned}
$$

Using the modified branching ratios, the identical calculation procedure for isotopic yields (eqs. S14 - S18) can be used to obtain the product $\mathrm{\delta}^{37} \mathrm{Cl}$ signatures. 


\section{Literature}

(1) Roberts, A. L.; Gschwend, P. M. Mechanisms of pentachloroethane dehydrochlorination to tetrachloroethylene Environ. Sci. Technol. 1991, 25, 76-86.

(2) Kohn, T.; Arnold, W. A.; Roberts, A. L. Reactivity of substituted benzotrichlorides toward granular iron, $\mathrm{Cr}(\mathrm{II})$, and an iron(II) porphyrin: A correlation analysis Environ. Sci. Technol. 2006, 40, 4253-4260.

(3) Kelsall, G. H.; House, C. I.; Gudyanga, F. P. Chemical and electrochemical equilibria and kinetics in aqueous $\mathrm{Cr}(\mathrm{III}) / \mathrm{Cr}(\mathrm{II})$ Chloride solutions J. Electroanal. Chem. 1988, 244, 179.

(4) Arnold, W. A.; Winget, P.; Cramer, C. J. Reductive dechlorination of 1,1,2,2-tetrachloroethane Environ. Sci. Technol. 2002, 36, 3536-3541.

(5) Zwank, L.; Elsner, M.; Aeberhard, A.; Schwarzenbach, R. P.; Haderlein, S. B. Carbon isotope fractionation in the reductive dehalogenation of carbon tetrachloride at iron (hydr)oxide and iron sulfide minerals Environ. Sci. Technol. 2005, 39, 5634-5641.

(6) Zwank, L.; Berg, M.; Schmidt, T. C.; Haderlein, S. B. Compound-specific carbon isotope analysis of volatile organic compounds in the low-microgram per liter range Anal. Chem. 2003, 75, 5575-5583.

(7) Gröning, M. International Stable Isotope Reference Materials. In Handbook of stable isotope analytical techniques; de Groot, P. A., Ed.; Elsevier: Amsterdam, 2004; Vol. 1, pp 874-906.

(8) Scott, K. M.; Lu, X.; Cavanaugh, C. M.; Liu, J. S. Optimal methods for estimating kinetic isotope effects from different forms of the Rayleigh distillation equation Geochim. Cosmochim. Acta 2004, 68, 433-442.

(9) Holt, B. D.; Heraty, L. J.; Sturchio, N. C. Extraction of chlorinated aliphatic hydrocarbons from groundwater at micromolar concentrations for isotopic analysis of chlorine Environmental Pollution 2001, 113, 263-269.

(10) Holt, B. D.; Sturchio, N. C.; Abrajano, T. A.; Heraty, L. J. Conversion of chlorinated volatile organic compounds to carbon dioxide and methyl chloride for isotopic analysis of carbon and chlorine Anal. Chem. 1997, 69, 2727-2733.

(11) Godon, A.; Jendrzejewski, N.; Eggenkamp, H. G. M.; Banks, D. A.; Ader, M.; Coleman, M. L.; Pineau, F. A cross-calibration of chlorine isotopic measurements and suitability of seawater as the international reference material Chem. Geol. 2004, 207, 1-12.

(12) Sturchio, N. C.; Hatzinger, P. B.; Arkins, M. D.; Suh, C.; Heraty, L. J. Chlorine isotope fractionation during microbial reduction of perchlorate Environ. Sci. Technol. 2003, 37, 38593863.

(13) Bevingtion, P. R.; Robinson, R. K. Data reduction and error analysis for the physical sciences; $3^{\text {rd }}$ ed.; McGraw-Hill: New York, 2003. 
Table S3 Fractional abundance, $\mathrm{P}_{\mathrm{i}}$, of binomially distributed 1,1,2,2-TeCA Cl-isotopologues ${ }^{\mathrm{a}}$ and reductive $\beta$-elmination branching ratios of subsequent ${ }^{35} \mathrm{Cl}-{ }^{35} \mathrm{Cl},{ }^{35} \mathrm{Cl}-{ }^{37} \mathrm{Cl},{ }^{37} \mathrm{Cl}-{ }^{35} \mathrm{Cl}$, and ${ }^{37} \mathrm{Cl}-{ }^{37} \mathrm{Cl}$.

\begin{tabular}{|c|c|c|c|c|c|}
\hline $\mathrm{i}$ & $\mathrm{n}_{\mathrm{Cl}, \mathrm{i}}^{37}(\alpha)$ & $\mathrm{n}_{\mathrm{Cl}, \mathrm{i}}^{37}(\beta)$ & $\mathrm{P}_{\mathrm{i}}$ & $\theta_{\mathrm{i}}^{35 / 35}$ & $\theta_{\mathrm{i}}^{35 / 37}$ \\
\hline 1 & 0 & 0 & 0.3296 & 1 & - \\
\hline 2 & 1 & 0 & 0.4216 & $\frac{4}{4+2 / \mathrm{KIE}_{\mathrm{Cl}}(2)+2 / \mathrm{KIE}_{\mathrm{Cl}}(1)}$ & $\frac{2 / \mathrm{KIE}_{\mathrm{Cl}}(2)}{4+2 / \mathrm{KIE}_{\mathrm{Cl}}(2)+2 / \mathrm{KIE}_{\mathrm{Cl}}(1)}$ \\
\hline $3 \mathrm{a}$ & 2 & 0 & 0.0674 & - & $\frac{4 / \mathrm{KIE}_{\mathrm{Cl}}(2)}{4 / \mathrm{KIE}_{\mathrm{Cl}}(2)+4 / \mathrm{KIE}_{\mathrm{Cl}}(1)}$ \\
\hline $3 \mathrm{~h}$ & 1 & 1 & 01348 & 2 & $2 / \mathrm{KIE}_{\mathrm{Cl}}(2)$ \\
\hline $3 \mathrm{~b}$ & 1 & 1 & 0.1348 & $2+2 / \mathrm{KIE}_{\mathrm{Cl}}(2)+2 / \mathrm{KIE}_{\mathrm{Cl}}(1)+2 / \mathrm{KIE}_{\mathrm{Cl}}(2) \cdot 1 / \mathrm{KIE}_{\mathrm{Cl}}(1)$ & $2+2 / \mathrm{KIE}_{\mathrm{Cl}}(2)+2 / \mathrm{KIE}_{\mathrm{Cl}}(1)+2 / \mathrm{KIE}_{\mathrm{Cl}}(2) \cdot 1 / \mathrm{KIE}_{\mathrm{Cl}}(1)$ \\
\hline 4 & 3 & 0 & 0.0431 & 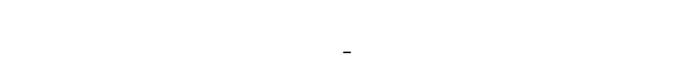 & $2 / \mathrm{KIE}_{\mathrm{Cl}}(2)$ \\
\hline 4 & 3 & 0 & 0.0431 & - & $2+2 / \mathrm{KIE}_{\mathrm{Cl}}(2)+2 / \mathrm{KIE}_{\mathrm{Cl}}(1)+4 / \mathrm{KIE}_{\mathrm{Cl}}(1) \cdot 1 / \mathrm{KIE}_{\mathrm{Cl}}(2)$ \\
\hline 5 & 4 & 0 & 0.0034 & - & - \\
\hline
\end{tabular}

\begin{tabular}{|c|c|c|c|c|c|}
\hline $\mathrm{i}$ & $\mathrm{n}_{\mathrm{Cl}, \mathrm{i}}^{37}(\alpha)$ & $\mathrm{n}_{\mathrm{Cl}, \mathrm{i}}^{37}(\beta)$ & $\mathrm{P}_{\mathrm{i}}$ & $\theta_{\mathrm{i}}^{37 / 35}$ & $\theta_{\mathrm{i}}^{37 / 37}$ \\
\hline 1 & 0 & 0 & 0.3296 & - & - \\
\hline 2 & 1 & 0 & 0.4216 & $\frac{2 / \mathrm{KIE}_{\mathrm{Cl}}(1)}{4+2 / \mathrm{KIE}_{\mathrm{Cl}}(2)+2 / \mathrm{KIE}_{\mathrm{Cl}}(1)}$ & - \\
\hline $3 \mathrm{a}$ & 2 & 0 & 0.1348 & $\frac{4 / \mathrm{KIE}_{\mathrm{Cl}}(1)}{4 / \mathrm{KIE}_{\mathrm{Cl}}(2)+4 / \mathrm{KIE}_{\mathrm{Cl}}(1)}$ & - \\
\hline \multirow{2}{*}{$3 b$} & \multirow{2}{*}{1} & \multirow{2}{*}{1} & \multirow{2}{*}{0.0674} & $2 / \mathrm{KIE}_{\mathrm{Cl}}(1)$ & $2 / \mathrm{KIE}_{\mathrm{Cl}}(2) \cdot 1 / \mathrm{KIE}_{\mathrm{Cl}}(1)$ \\
\hline & & & & $2+2 / \mathrm{KIE}_{\mathrm{Cl}}(2)+2 / \mathrm{KIE}_{\mathrm{Cl}}(1)+2 / \mathrm{KIE}_{\mathrm{Cl}}(2) \cdot 1 / \mathrm{KIE}_{\mathrm{Cl}}(1)$ & $2+2 / \mathrm{KIE}_{\mathrm{Cl}}(2)+2 / \mathrm{KIE}_{\mathrm{Cl}}(1)+2 / \mathrm{KIE}_{\mathrm{Cl}}(2) \cdot 1 / \mathrm{KIE}_{\mathrm{Cl}}(1)$ \\
\hline \multirow{2}{*}{4} & \multirow{2}{*}{3} & \multirow{2}{*}{0} & \multirow{2}{*}{0.0431} & $2 / \mathrm{KIE}_{\mathrm{Cl}}(1)$ & $4 / \mathrm{KIE}_{\mathrm{Cl}}(1) \cdot 1 / \mathrm{KIE}_{\mathrm{Cl}}(2)$ \\
\hline & & & & $2+2 / \mathrm{KIE}_{\mathrm{Cl}}(2)+2 / \mathrm{KIE}_{\mathrm{Cl}}(1)+4 / \mathrm{KIE}_{\mathrm{Cl}}(1) \cdot 1 / \mathrm{KIE}_{\mathrm{Cl}}(2)$ & $2+2 / \mathrm{KIE}_{\mathrm{Cl}}(2)+2 / \mathrm{KIE}_{\mathrm{Cl}}(1)+4 / \mathrm{KIE}_{\mathrm{Cl}}(1) \cdot 1 / \mathrm{KIE}_{\mathrm{Cl}}(2)$ \\
\hline 5 & 4 & 0 & 0.0034 & - & 1 \\
\hline
\end{tabular}


Table S4 Fractional abundance, $\mathrm{P}_{\mathrm{i}}$, of binomially distributed $\mathrm{PCA} \mathrm{Cl}$-isotopologues ${ }^{\mathrm{a}}$ and reductive $\beta$-elmination branching ratios of subsequent ${ }^{35} \mathrm{Cl}-{ }^{35} \mathrm{Cl},{ }^{35} \mathrm{Cl}-{ }^{37} \mathrm{Cl},{ }^{37} \mathrm{Cl}-{ }^{35} \mathrm{Cl}$, and ${ }^{37} \mathrm{Cl}-{ }^{37} \mathrm{Cl}$.

\begin{tabular}{|c|c|c|c|c|c|}
\hline $\mathrm{i}$ & $\mathrm{n}_{\mathrm{Cl}, \mathrm{i}}^{37}(\alpha)$ & $\mathrm{n}_{\mathrm{Cl}, \mathrm{i}}^{37}(\beta)$ & $\mathrm{P}_{\mathrm{i}}$ & $\theta_{\mathrm{i}}^{35 / 35}$ & $\theta_{\mathrm{i}}^{35 / 37}$ \\
\hline 1 & 0 & 0 & 0.2487 & 1 & - \\
\hline \multirow[t]{2}{*}{$2 \mathrm{a}$} & 1 & 0 & 0.2394 & $\begin{array}{r}8 \\
\end{array}$ & $2 / \mathrm{KIE}_{\mathrm{Cl}}(2)$ \\
\hline & & & & $8+2 / \mathrm{KIE}_{\mathrm{Cl}}(2)+2 / \mathrm{KIE}_{\mathrm{Cl}}(1)$ & $\overline{8+2 / \mathrm{KIE}_{\mathrm{Cl}}(2)+2 / \mathrm{KIE}_{\mathrm{Cl}}(1)}$ \\
\hline \multirow[t]{2}{*}{$2 b$} & 0 & 1 & 0.1596 & 6 & $3 / \operatorname{KIE}(1)$ \\
\hline & & & & $\overline{6+3 / \mathrm{KIE}_{\mathrm{Cl}}(1)+3 / \mathrm{KIE}_{\mathrm{Cl}}(2)}$ & $\overline{6+3 / \mathrm{KIE}_{\mathrm{Cl}}(1)+3 / \mathrm{KIE}_{\mathrm{Cl}}(2)}$ \\
\hline \multirow[t]{2}{*}{$3 \mathrm{a}$} & 2 & 0 & 0.0768 & 4 & $4 / \mathrm{KIE}_{\mathrm{Cl}}(2)$ \\
\hline & & & & $\overline{4+4 / \mathrm{KIE}_{\mathrm{Cl}}(2)+4 / \mathrm{KIE}_{\mathrm{Cl}}(1)}$ & $\overline{4+4 / \mathrm{KIE}_{\mathrm{Cl}}(2)+4 / \mathrm{KIE}_{\mathrm{Cl}}(1)}$ \\
\hline \multirow[t]{2}{*}{$3 b$} & 1 & 1 & 0.1536 & 4 & $3 / \mathrm{KIE}_{\mathrm{Cl}}(2)$ \\
\hline & & & & $\overline{4+3 / \mathrm{KIE}_{\mathrm{Cl}}(2)+3 / \mathrm{KIE}_{\mathrm{Cl}}(1)+2 / \mathrm{KIE}_{\mathrm{Cl}}(1) \cdot 1 / \mathrm{KIE}_{\mathrm{Cl}}(2)}$ & $4+3 / \mathrm{KIE}_{\mathrm{Cl}}(2)+3 / \mathrm{KIE}_{\mathrm{Cl}}(1)+2 / \mathrm{KIE}_{\mathrm{Cl}}(1) \cdot 1 / \mathrm{KIE}_{\mathrm{Cl}}(2)$ \\
\hline \multirow[t]{2}{*}{$3 \mathrm{c}$} & 0 & 2 & 0.0256 & - & $6 / \mathrm{KIE}_{\mathrm{Cl}}(2)$ \\
\hline & & & & & $\overline{6 / \mathrm{KIE}_{\mathrm{Cl}}(2)+6 / \mathrm{KIE}_{\mathrm{Cl}}(1)}$ \\
\hline \multirow[t]{2}{*}{$4 a$} & 3 & 0 & 0.0082 & - & $6 / \mathrm{KIE}_{\mathrm{Cl}}(2)$ \\
\hline & & & & & $\overline{6 / \mathrm{KIE}_{\mathrm{Cl}}(2)+6 / \mathrm{KIE}_{\mathrm{Cl}}(1)}$ \\
\hline \multirow[t]{2}{*}{$4 b$} & 2 & 1 & 0.0493 & 2 & $3 / \mathrm{KIE}_{\mathrm{Cl}}(2)$ \\
\hline & & & & $\overline{2+3 / \mathrm{KIE}_{\mathrm{Cl}}(2)+3 / \mathrm{KIE}_{\mathrm{Cl}}(1)+4 / \mathrm{KIE}_{\mathrm{Cl}}(1) \cdot 1 / \mathrm{KIE}_{\mathrm{Cl}}(2)}$ & $\overline{2+3 / \mathrm{KIE}_{\mathrm{Cl}}(2)+3 / \mathrm{KIE}_{\mathrm{Cl}}(1)+4 / \mathrm{KIE}_{\mathrm{Cl}}(1) \cdot 1 / \mathrm{KIE}_{\mathrm{Cl}}(2)}$ \\
\hline \multirow[t]{2}{*}{$4 c$} & 1 & 2 & 0.0246 & - & $4 / \mathrm{KIE}_{\mathrm{Cl}}(2)$ \\
\hline & & & & & $\overline{4 / \mathrm{KIE}_{\mathrm{Cl}}(2)+4 / \mathrm{KIE}_{\mathrm{Cl}}(1)+4 / \mathrm{KIE}_{\mathrm{Cl}}(1) \cdot 1 / \mathrm{KIE}_{\mathrm{Cl}}(2)}$ \\
\hline \multirow[t]{2}{*}{$5 \mathrm{a}$} & 3 & 1 & 0.0053 & - & $3 / \mathrm{KIE}_{\mathrm{Cl}}(2)$ \\
\hline & & & & & $3 / \mathrm{KIE}_{\mathrm{Cl}}(2)+3 / \mathrm{KIE}_{\mathrm{Cl}}(1)+6 / \mathrm{KIE}_{\mathrm{Cl}}(1) \cdot 1 / \mathrm{KIE}_{\mathrm{Cl}}(2)$ \\
\hline \multirow[t]{2}{*}{$5 b$} & 2 & 2 & 0.0079 & - & $2 / \mathrm{KIE}_{\mathrm{Cl}}(2)$ \\
\hline & & & & & $2 / \mathrm{KIE}_{\mathrm{Cl}}(2)+2 / \mathrm{KIE}_{\mathrm{Cl}}(1)+8 / \mathrm{KIE}_{\mathrm{Cl}}(1) \cdot 1 / \mathrm{KIE}_{\mathrm{Cl}}(2)$ \\
\hline 6 & 3 & 2 & 0.0008 & - & - \\
\hline
\end{tabular}


Table S4 continued

\begin{tabular}{|c|c|c|c|c|c|}
\hline $\mathrm{i}$ & $\mathrm{n}_{\mathrm{Cl}, \mathrm{i}}^{37}(\alpha)$ & $\mathrm{n}_{\mathrm{Cl}, \mathrm{i}}^{37}(\beta)$ & $\mathrm{P}_{\mathrm{i}}$ & $\theta_{i}^{37 / 35}$ & $\theta_{\mathrm{i}}^{37 / 37}$ \\
\hline 1 & 0 & 0 & 0.2487 & - & - \\
\hline $2 \mathrm{a}$ & 1 & 0 & 0.2394 & $\frac{2 / \mathrm{KIE}_{\mathrm{Cl}}(1)}{8+2 / \mathrm{KIE}_{\mathrm{Cl}}(2)+2 / \mathrm{KIE}_{\mathrm{Cl}}(1)}$ & - \\
\hline $2 b$ & 0 & 1 & 0.1596 & $\frac{3 / \mathrm{KIE}_{\mathrm{Cl}}(2)}{6+3 / \mathrm{KIE}_{\mathrm{Cl}}(1)+3 / \mathrm{KIE}_{\mathrm{Cl}}(2)}$ & - \\
\hline $3 a$ & 2 & 0 & 0.0768 & $\frac{4 / \mathrm{KIE}_{\mathrm{Cl}}(1)}{4+4 / \mathrm{KIE}_{\mathrm{Cl}}(2)+4 / \mathrm{KIE}_{\mathrm{Cl}}(1)}$ & \\
\hline $3 b$ & 1 & 1 & 0.1536 & $\frac{3 / \mathrm{KIE}_{\mathrm{Cl}}(1)}{4+3 / \mathrm{KIE}_{\mathrm{Cl}}(2)+3 / \mathrm{KIE}_{\mathrm{Cl}}(1)+2 / \mathrm{KIE}_{\mathrm{Cl}}(1) \cdot 1 / \mathrm{KIE}_{\mathrm{Cl}}(2)}$ & $\frac{2 / \mathrm{KIE}_{\mathrm{Cl}}(1) \cdot 1 / \mathrm{KIE}_{\mathrm{Cl}}(2)}{4+3 / \mathrm{KIE}_{\mathrm{Cl}}(2)+3 / \mathrm{KIE}_{\mathrm{Cl}}(1)+2 / \mathrm{KIE}_{\mathrm{Cl}}(1) \cdot 1 / \mathrm{KIE}_{\mathrm{Cl}}(2)}$ \\
\hline $3 c$ & 0 & 2 & 0.0256 & $\frac{6 / \mathrm{KIE}_{\mathrm{Cl}}(1)}{6 / \mathrm{KIE}_{\mathrm{Cl}}(2)+6 / \mathrm{KIE}_{\mathrm{Cl}}(1)}$ & - \\
\hline $4 a$ & 3 & 0 & 0.0082 & $\frac{6 / \mathrm{KIE}_{\mathrm{Cl}}(1)}{6 / \mathrm{KIE}_{\mathrm{Cl}}(2)+6 / \mathrm{KIE}_{\mathrm{Cl}}(1)}$ & - \\
\hline $4 \mathrm{~b}$ & 2 & 1 & 0.0493 & $3 / \mathrm{KIE}_{\mathrm{Cl}}(1)$ & $4 / \mathrm{KIE}_{\mathrm{Cl}}(1) \cdot 1 / \mathrm{KIE}_{\mathrm{Cl}}(2)$ \\
\hline & & & & $2+3 / \mathrm{KIE}_{\mathrm{Cl}}(2)+3 / \mathrm{KIE}_{\mathrm{Cl}}(1)+4 / \mathrm{KIE}_{\mathrm{Cl}}(1) \cdot 1 / \mathrm{KIE}_{\mathrm{Cl}}(2)$ & $2+3 / \mathrm{KIE}_{\mathrm{Cl}}(2)+3 / \mathrm{KIE}_{\mathrm{Cl}}(1)+4 / \mathrm{KIE}_{\mathrm{Cl}}(1) \cdot 1 / \mathrm{KIE}_{\mathrm{Cl}}(2)$ \\
\hline $4 c$ & 1 & 2 & 0.0246 & $\frac{4 / \mathrm{KIE}_{\mathrm{Cl}}(1)}{4 / \mathrm{KIE}_{\mathrm{Cl}}(2)+4 / \mathrm{KIE}_{\mathrm{Cl}}(1)+4 / \mathrm{KIE}_{\mathrm{Cl}}(1) \cdot 1 / \mathrm{KIE}_{\mathrm{Cl}}(2)}$ & $\frac{4 / \mathrm{KIE}_{\mathrm{Cl}}(1) \cdot 1 / \mathrm{KIE}_{\mathrm{Cl}}(2)}{4 / \mathrm{KIE}_{\mathrm{Cl}}(2)+4 / \mathrm{KIE}_{\mathrm{Cl}}(1)+4 / \mathrm{KIE}_{\mathrm{Cl}}(1) \cdot 1 / \mathrm{KIE}_{\mathrm{Cl}}(2)}$ \\
\hline $5 a$ & 3 & 1 & 0.0053 & $\frac{3 / \mathrm{KIE}_{\mathrm{Cl}}(1)}{3 / \mathrm{KIE}_{\mathrm{Cl}}(2)+3 / \mathrm{KIE}_{\mathrm{Cl}}(1)+6 / \mathrm{KIE}_{\mathrm{Cl}}(1) \cdot 1 / \mathrm{KIE}_{\mathrm{Cl}}(2)}$ & $\frac{6 / \mathrm{KIE}_{\mathrm{Cl}}(1) \cdot 1 / \mathrm{KIE}_{\mathrm{Cl}}(2)}{3 / \mathrm{KIE}_{\mathrm{Cl}}(2)+3 / \mathrm{KIE}_{\mathrm{Cl}}(1)+6 / \mathrm{KIE}_{\mathrm{Cl}}(1) \cdot 1 / \mathrm{KIE}_{\mathrm{Cl}}(2)}$ \\
\hline $5 b$ & 2 & 2 & 0.0079 & $\frac{2 / \mathrm{KIE}_{\mathrm{Cl}}(1)}{2 / \mathrm{KIE}_{\mathrm{Cl}}(2)+2 / \mathrm{KIE}_{\mathrm{Cl}}(1)+8 / \mathrm{KIE}_{\mathrm{Cl}}(1) \cdot 1 / \mathrm{KIE}_{\mathrm{Cl}}(2)}$ & $\frac{8 / \mathrm{KIE}_{\mathrm{Cl}}(1) \cdot 1 / \mathrm{KIE}_{\mathrm{Cl}}(2)}{2 / \mathrm{KIE}_{\mathrm{Cl}}(2)+2 / \mathrm{KIE}_{\mathrm{Cl}}(1)+8 / \mathrm{KIE}_{\mathrm{Cl}}(1) \cdot 1 / \mathrm{KIE}_{\mathrm{Cl}}(2)}$ \\
\hline 6 & 3 & 2 & 0.0008 & - & 1 \\
\hline
\end{tabular}

\footnotetext{
${ }^{a}$ Initial $\delta^{37} \mathrm{Cl}$-signature was $3.367 \%$, $\pi_{\mathrm{R}}$ equals 0.2429 .
} 
Table S5 Fractional abundance, $\mathrm{P}_{\mathrm{i}}$, of binomially distributed hexachloroethane (HCA) $\mathrm{Cl}$-isotopologues ${ }^{\mathrm{a}}$ and reductive $\beta$-elmination branching ratios of subsequent ${ }^{35} \mathrm{Cl}-{ }^{35} \mathrm{Cl},{ }^{35} \mathrm{Cl}-{ }^{37} \mathrm{Cl},{ }^{37} \mathrm{Cl}-{ }^{35} \mathrm{Cl}$, and ${ }^{37} \mathrm{Cl}-{ }^{37} \mathrm{Cl}$.

\begin{tabular}{|c|c|c|c|c|c|}
\hline $\mathrm{i}$ & $\mathrm{n}_{\mathrm{Cl}, \mathrm{i}}^{37}(\alpha)$ & $\mathrm{n}_{\mathrm{Cl}, \mathrm{i}}^{37}(\beta)$ & $\mathrm{P}_{\mathrm{i}}$ & $\theta_{\mathrm{i}}^{35 / 35}$ & $\theta_{\mathrm{i}}^{35 / 37}$ \\
\hline 1 & 0 & 0 & 0.1890 & 1 & - \\
\hline \multirow[t]{2}{*}{2} & 1 & 0 & 0.3629 & 12 & $3 / \mathrm{KIE}_{\mathrm{Cl}}(2)$ \\
\hline & & & & $12+3 / \mathrm{KIE}_{\mathrm{Cl}}(2)+3 / \mathrm{KIE}_{\mathrm{Cl}}(1)$ & $\overline{12+3 / \mathrm{KIE}_{\mathrm{Cl}}(2)+3 / \mathrm{KIE}_{\mathrm{Cl}}(1)}$ \\
\hline \multirow[t]{2}{*}{$3 \mathrm{a}$} & 2 & 0 & 0.1162 & 6 & $6 / \mathrm{KIE}_{\mathrm{Cl}}(2)$ \\
\hline & & & & $\overline{6+6 / \mathrm{KIE}_{\mathrm{Cl}}(2)+6 / \mathrm{KIE}_{\mathrm{Cl}}(1)}$ & $\overline{6+6 / \mathrm{KIE}_{\mathrm{Cl}}(2)+6 / \mathrm{KIE}_{\mathrm{Cl}}(1)}$ \\
\hline \multirow[t]{2}{*}{$3 b$} & 1 & 1 & 0.1742 & 8 & $4 / \mathrm{KIE}_{\mathrm{Cl}}(2)$ \\
\hline & & & & $8+4 / \mathrm{KIE}_{\mathrm{Cl}}(2)+4 / \mathrm{KIE}_{\mathrm{Cl}}(1)+2 / \mathrm{KIE}_{\mathrm{Cl}}(2) \cdot 1 / \mathrm{KIE}_{\mathrm{Cl}}(1)$ & $8+4 / \mathrm{KIE}_{\mathrm{Cl}}(2)+4 / \mathrm{KIE}_{\mathrm{Cl}}(1)+2 / \mathrm{KIE}_{\mathrm{Cl}}(2) \cdot 1 / \mathrm{KIE}_{\mathrm{Cl}}(1)$ \\
\hline \multirow[t]{2}{*}{$4 \mathrm{a}$} & 3 & 0 & 0.0124 & & $9 / \mathrm{KIE}_{\mathrm{Cl}}(2)$ \\
\hline & & & & & $\overline{9 / \mathrm{KIE}_{\mathrm{Cl}}(2)+9 / \mathrm{KIE}_{\mathrm{Cl}}(1)}$ \\
\hline \multirow[t]{2}{*}{$4 b$} & 2 & 1 & 0.1115 & 4 & $5 / \mathrm{KIE}_{\mathrm{Cl}}(2)$ \\
\hline & & & & $\overline{4+5 / \mathrm{KIE}_{\mathrm{Cl}}(2)+5 / \mathrm{KIE}_{\mathrm{Cl}}(1)+4 / \mathrm{KIE}_{\mathrm{Cl}}(1) \cdot 1 / \mathrm{KIE}_{\mathrm{Cl}}(2)}$ & $\overline{4+5 / \mathrm{KIE}_{\mathrm{Cl}}(2)+5 / \mathrm{KIE}_{\mathrm{Cl}}(1)+4 / \mathrm{KIE}_{\mathrm{Cl}}(1) \cdot 1 / \mathrm{KIE}_{\mathrm{Cl}}(2)}$ \\
\hline \multirow[t]{2}{*}{$5 \mathrm{a}$} & 3 & 1 & 0.0119 & - & $6 / \mathrm{KIE}_{\mathrm{Cl}}(2)$ \\
\hline & & & & & $\overline{6 / \mathrm{KIE}_{\mathrm{Cl}}(2)+6 / \mathrm{KIE}_{\mathrm{Cl}}(1)+6 / \mathrm{KIE}_{\mathrm{Cl}}(1) \cdot 1 / \mathrm{KIE}_{\mathrm{Cl}}(2)}$ \\
\hline \multirow[t]{2}{*}{$5 b$} & 2 & 2 & 0.0179 & 2 & $4 / \mathrm{KIE}_{\mathrm{Cl}}(2)$ \\
\hline & & & & $\overline{2+4 / \mathrm{KIE}_{\mathrm{Cl}}(2)+4 / \mathrm{KIE}_{\mathrm{Cl}}(1)+8 / \mathrm{KIE}_{\mathrm{Cl}}(1) \cdot 1 / \mathrm{KIE}_{\mathrm{Cl}}(2)}$ & $2+4 / \mathrm{KIE}_{\mathrm{Cl}}(2)+4 / \mathrm{KIE}_{\mathrm{Cl}}(1)+8 / \mathrm{KIE}_{\mathrm{Cl}}(1) \cdot 1 / \mathrm{KIE}_{\mathrm{Cl}}(2)$ \\
\hline \multirow[t]{2}{*}{6} & 3 & 2 & 0.0038 & - & $3 / \mathrm{KIE}_{\mathrm{Cl}}(2)$ \\
\hline & & & & & $\overline{3 / \mathrm{KIE}_{\mathrm{Cl}}(2)+3 / \mathrm{KIE}_{\mathrm{Cl}}(1)+12 / \mathrm{KIE}_{\mathrm{Cl}}(1) \cdot 1 / \mathrm{KIE}_{\mathrm{Cl}}(2)}$ \\
\hline 7 & 3 & 3 & 0.0002 & - & - \\
\hline
\end{tabular}


Table S5 continued

\begin{tabular}{|c|c|c|c|c|c|}
\hline $\mathrm{i}$ & $\mathrm{n}_{\mathrm{Cl}, \mathrm{i}}^{37}(\alpha)$ & $\mathrm{n}_{\mathrm{Cl}, \mathrm{i}}^{37}(\beta)$ & $P_{i}$ & $\theta_{\mathrm{i}}^{37 / 35}$ & $\theta_{\mathrm{i}}^{37 / 37}$ \\
\hline 1 & 0 & 0 & 0.1890 & - & - \\
\hline 2 & 1 & 0 & 0.3629 & $\frac{3 / \mathrm{KIE}_{\mathrm{Cl}}(1)}{12+3 / \mathrm{KIE}_{\mathrm{Cl}}(2)+3 / \mathrm{KIE}_{\mathrm{Cl}}(1)}$ & - \\
\hline $3 a$ & 2 & 0 & 0.1162 & $\frac{6 / \mathrm{KIE}_{\mathrm{Cl}}(1)}{6+6 / \mathrm{KIE}_{\mathrm{Cl}}(2)+6 / \mathrm{KIE}_{\mathrm{Cl}}(1)}$ & \\
\hline \multirow[t]{2}{*}{$3 b$} & 1 & 1 & 0.1742 & $4 / \mathrm{KIE}_{\mathrm{Cl}}(1)$ & $2 / \mathrm{KIE}_{\mathrm{Cl}}(2) \cdot 1 / \mathrm{KIE}_{\mathrm{Cl}}(1)$ \\
\hline & & & & $8+4 / \mathrm{KIE}_{\mathrm{Cl}}(2)+4 / \mathrm{KIE}_{\mathrm{Cl}}(1)+2 / \mathrm{KIE}_{\mathrm{Cl}}(2) \cdot 1 / \mathrm{KIE}_{\mathrm{Cl}}(1)$ & $8+4 / \mathrm{KIE}_{\mathrm{Cl}}(2)+4 / \mathrm{KIE}_{\mathrm{Cl}}(1)+2 / \mathrm{KIE}_{\mathrm{Cl}}(2) \cdot 1 / \mathrm{KIE}_{\mathrm{Cl}}(1)$ \\
\hline $4 \mathrm{a}$ & 3 & 0 & 0.0124 & $\frac{9 / \mathrm{KIE}_{\mathrm{Cl}}(1)}{9 / \mathrm{KIE}_{\mathrm{Cl}}(2)+9 / \mathrm{KIE}_{\mathrm{Cl}}(1)}$ & \\
\hline \multirow[t]{2}{*}{$4 b$} & 2 & 1 & 0.1115 & $5 / \operatorname{KIE}_{\mathrm{Cl}}(1)$ & $4 / \mathrm{KIE}_{\mathrm{Cl}}(1) \cdot 1 / \mathrm{KIE}_{\mathrm{Cl}}(2)$ \\
\hline & & & & $\overline{4+5 / \mathrm{KIE}_{\mathrm{Cl}}(2)+5 / \mathrm{KIE}_{\mathrm{Cl}}(1)+4 / \mathrm{KIE}_{\mathrm{Cl}}(1) \cdot 1 / \mathrm{KIE}_{\mathrm{Cl}}(2)}$ & $4+5 / \mathrm{KIE}_{\mathrm{Cl}}(2)+5 / \mathrm{KIE}_{\mathrm{Cl}}(1)+4 / \mathrm{KIE}_{\mathrm{Cl}}(1) \cdot 1 / \mathrm{KIE}_{\mathrm{Cl}}(2)$ \\
\hline \multirow[t]{2}{*}{$5 \mathrm{a}$} & 3 & 1 & 0.0119 & $6 / \mathrm{KIE}_{\mathrm{Cl}}(1)$ & $6 / \mathrm{KIE}_{\mathrm{Cl}}(1) \cdot 1 / \mathrm{KIE}_{\mathrm{Cl}}(2)$ \\
\hline & & & & $6 / \mathrm{KIE}_{\mathrm{Cl}}(2)+6 / \mathrm{KIE}_{\mathrm{Cl}}(1)+6 / \mathrm{KIE}_{\mathrm{Cl}}(1) \cdot 1 / \mathrm{KIE}_{\mathrm{Cl}}(2)$ & $6 / \mathrm{KIE}_{\mathrm{Cl}}(2)+6 / \mathrm{KIE}_{\mathrm{Cl}}(1)+6 / \mathrm{KIE}_{\mathrm{Cl}}(1) \cdot 1 / \mathrm{KIE}_{\mathrm{Cl}}(2)$ \\
\hline \multirow[t]{2}{*}{$5 b$} & 2 & 2 & 0.0179 & $4 / \mathrm{KIE}_{\mathrm{Cl}}(1)$ & $8 / \mathrm{KIE}_{\mathrm{Cl}}(1) \cdot 1 / \mathrm{KIE}_{\mathrm{Cl}}(2)$ \\
\hline & & & & $2+4 / \mathrm{KIE}_{\mathrm{Cl}}(2)+4 / \mathrm{KIE}_{\mathrm{Cl}}(1)+8 / \mathrm{KIE}_{\mathrm{Cl}}(1) \cdot 1 / \mathrm{KIE}_{\mathrm{Cl}}(2)$ & $2+4 / \mathrm{KIE}_{\mathrm{Cl}}(2)+4 / \mathrm{KIE}_{\mathrm{Cl}}(1)+8 / \mathrm{KIE}_{\mathrm{Cl}}(1) \cdot 1 / \mathrm{KIE}_{\mathrm{Cl}}(2)$ \\
\hline \multirow[t]{2}{*}{6} & 3 & 2 & 0.0038 & $3 / \mathrm{KIE}_{\mathrm{Cl}}(1)$ & $12 / \mathrm{KIE}_{\mathrm{Cl}}(1) \cdot 1 / \mathrm{KIE}_{\mathrm{Cl}}(2)$ \\
\hline & & & & $3 / \mathrm{KIE}_{\mathrm{Cl}}(2)+3 / \mathrm{KIE}_{\mathrm{Cl}}(1)+12 / \mathrm{KIE}_{\mathrm{Cl}}(1) \cdot 1 / \mathrm{KIE}_{\mathrm{Cl}}(2)$ & $3 / \mathrm{KIE}_{\mathrm{Cl}}(2)+3 / \mathrm{KIE}_{\mathrm{Cl}}(1)+12 / \mathrm{KIE}_{\mathrm{Cl}}(1) \cdot 1 / \mathrm{KIE}_{\mathrm{Cl}}(2)$ \\
\hline 7 & 3 & 3 & 0.0002 & - & 1 \\
\hline
\end{tabular}

\footnotetext{
${ }^{\mathrm{a}}$ Initial $\delta^{37} \mathrm{Cl}$-signature was $0.954 \%$, $\pi_{\mathrm{R}}$ equals 0.2425 .
} 